\title{
HiLlaire, N. (2019). LA RÉPARATION DANS L'ART. PARIS: Nouvelles Éditions Scala.
}

\author{
Dina Germanos Besson \\ Investigadora independente (psicanalista)
}

O que dizer sobre este livro? Que não é um livro, mas um monumento (no sentido de um teatro de memória ou teatro da memória), ou melhor, um arquipélago. Ele é estonteante. $\mathrm{O}$ que Norbert Hillaire empresta da abordagem arquipelágica (mesmo que a expressão não tenha sido usada pelo autor) é a postura do artista que, estrangeiro ou exilado em si mesmo, afasta-se da essência, para olhar o mundo como uma diferença uma lacuna que constitui um novo significado. Consequentemente, a estrutura é modelada na descontinuidade do tempo, ou melhor, na sua fragilidade, libertando-se de todas as pretensões demiúrgicas, curvando-se sobre "as mais pequenas expressões dos dias seguintes aos dias" (pp. 342-343).

O leitor então compreende o ritmo da obra: cada parte é um encerramento. Mas uma cerca imperfeita que, clandestinamente, sinaliza para a parte que a segue. A obra também é labiríntica, tecida com múltiplas ramificações, onde cada labirinto é separado do seguinte por um desvio, um interstício, um hiato, ocultando um ato artístico. Entre cada ato - ou seja, esse evento único que se afasta de qualquer norma estabelecida - e o próximo, o universo esboçado é destruído e renasce: logo que levantados, os fragmentos são destruídos, permanecendo como inacabados (work in progress), assim como obras artesanais de artistas que, por serem vulneráveis, quebradas ou justamente feridas, participam de um novo sentido, desregulado e inesgotável, tornando-se obras abertas.

Assim, nós caímos de surpresa em surpresa, à imagem desta oportunidade sempre perdida: um encontro casual entre uma máquina de costura e um guarda-chuva. O leitor então visita o universo de Ponge, esse poeta que teve apenas um curto intervalo para rastrear o objeto via um inventário poético do léxico, sem delimitá-lo; os estilhaços das palavras de Artaud, "nunca irreconciliáveis e irreconciliados consigo mesmos e com o mundo" (p. 47); o Kintsugi que, em vez de a reparação, tenta, pelo contrário, mostrá-lo, deixar um rastro, redescobrindo a história do objeto, mas um objeto que "se bifurca" ou que não coincide consigo mesmo, inscrevendo-senuma "estética do defeito". Graças a essa linguagem desviante, ele torna-se um "objeto mais belo".

De fato, com este livro, assistimos ao colapso do sistema, ou seja, o colapso de todos os dados figurativos ou clichês, para ver o surgimento de fragmentos, "uma estética do acidente", do híbrido, dos trabalhos manuais efémeros, "de que só nos lembraremos da beleza do gesto que o apoia, e não o objetivo que visa" (p. 116), novas expressões que desconstroem o militantismo e as certezas, o "coeficiente de arte" de Duchamp (p. 88), esta dimensão que foge do alcance de todos, do jogo contínuo que desequilibra as escalas, distorce o excesso ou que recorre à astúcia, ao métis e a outras estratégias de 
deslocamento: disfarce, travestimento, colagem, logotipo, ornamento e assim por diante... O desaparecimento do " $\mathrm{e}$ " de Perec, finalmente, que, evocando "o desaparecimento erigido como um princípio monstruoso" (p. 281), anuncia, por essa falta, o surgimento de uma nova literatura. O livro termina então com um hino à linguagem: um convite para a sua renovação. Cabe ao leitor descobrir isso.

Como classificar este trabalho, tão bem organizado sob a sua aparente desordem, tão humano, tão enigmático? Não podemos dizer que é um livro sobre a arte, ou pelo menos não pode ser reduzido a isto. Também não podemos chamá-lo de "ensaio", no sentido de uma obra que supõe uma construção, um devir, a tecelagem da irreversibilidade do tempo. Diferentemente, trata-se de migalhas artísticas, onde o tempo redescoberto é concebido como um futuro anterior, como "uma percolação do passado no presente", como um "passado reinventado" ou como o farfalhar de dois tempos onde um deles já não existe, e o outro ainda não. E dessa fenda surgirá a figura, para usar uma expressão de Deleuze e Bacon (2002, pp. 66-67), à imagem da irrupção involuntária de Combray numa chávena de chá.

A propósito desta obra vertiginosa, portanto, e com um sotaque de Borges, direi: os meus olhos terão visto esse objeto profano e acidental, do qual os homens usurpam o nome, mas que nenhum escritor até então conseguiu abraçar; a reparação impossível. Através dos artistas mencionados, o autor dá forma a esse impossível. E é a maneira singular de apreender o impossível, o seu fracasso, que fará o ato reparador, ou seja, também o estilo do artista.

E qual é o impossível (e não a impotência) que tenta dizer-se ao longo da obra: esse universo inconcebível?

Preso no turbilhão de uma aparente obscenidade que nos impede de acreditar na nossa existência real - à imagem do "patrão" de Robbe-Grillet que se dissolve na decoração ou à imagem desse ilimitadode que o autor fala, que visa eliminar o resto, loucuratranshumanista, se houver uma - podemos livrar-nos desse estupor nauseante em que a atmosfera neoliberal nos mergulha, essa mesma experiência do mundo contemporâneo? O obstáculo em que parecemos estar murados não leva nem ao tédio nem ao desespero; não mais do que à revolta - sem dúvida acabada. O resultado virá de um "ar de jazz", como o outro disse, um ar de jazz como uma arte de viver.

A urgência é de fato abandonar a promessa formatada, objeto pré-fabricado, degradante ao impudor, produto triste e decaído da modernidade. Essa renúncia será acompanhada de outro ganho: uma poética que não existe apenas na poesia. A sua potência, a sua criatividade exerce o seu poder em outro lugar, na vida, sobre a vida. É o gesto artístico que sempre parece estar à espera da sua unidade; e é precisamente essa instabilidade, essa precariedade, que contribuem para tornar a vida um teste permanente de lirismo, condição necessária para a invenção de umapalavra singular, aquela que está em busca de algo, de um objeto que foge, vacilante e improvável; e que coloca a sua interrogação inquieta, à imagem de um íntimo a circunscrever. É este desconhecido do sujeito que as palavras e o ato artístico, nas suas próprias hesitações, nos seus próprios fracassos, tentam definir. O musical surge como o Outro da língua: um jene sais quoi 
que proclama a nomeação impossível, enquanto glorifica esse ar, fugitivo e volátil, que zomba da sua fuga. Só podemos saudar a caneta do autor que conseguiu introduzir essa música na prosa escrita, um ar que triunfa nasua Veneza e um arque apenas uma música trémula pode fazer ouvir fugazmente.

Assim, a face obscena das coisas não prevalecerá; e o poder da arte vem da sua capacidade de se dissimular como arte. Caberá a nós decifrar os caminhos difíceis da desalienação, da poesia silenciosa, da pintura falante, albergando a polifonia conflituosa e indizível - como A Biblioteca de Babel (Borges, 1993), com uma estrutura cabalística, secretamente trabalhando em todos nós e neste livro. Porque o problema deste drama humano é para sempre sem solução, é, enquanto drama, a própria possibilidade de renovação. Nunca trancado numa linguagem, sempre pronto para a obra, enigma para si mesmo. Incansavelmente.

Tradução: Pedro Andrade

\section{REFERÊNCIAS}

Borges, J. (1993). La Bibiliothèque de Babel. Paris: Gallimard.

Deleuze, G. \& Bacon, F. (2002). Logique de la sensation. Paris: Seuil.

\section{NOTA BIOGRÁFICA}

Dina Germanos Besson é psicanalista em Toulouse, França. Membro de Espace Analytique. Doutora em Psicologia e professora de Literatura Moderna. Autora de livros e artigos publicados em periódicos nacionais e internacionais. Os seus temas de pesquisa tratam dos efeitos do discurso (vínculos sociais) sobre o sujeito e as instituições simbólicas.

ORCID: https://orcid.org/oooo-0oo2-6999-2672

Email: dina.besson@gmail.com

Morada: 29 rue de Metz, 31000 Toulouse, France

\section{Submetido: 10/09/2019}

Aceite: $30 / 11 / 2019$ 